\title{
Rhysacephala novacaledonica sp. nov. (Hymenoptera: Xiphydriidae), the first xiphydriid woodwasp from New Caledonia
}

\author{
JOHN T. JENNINGS ${ }^{1}$, ANDREW D. AUSTIN ${ }^{1}$ AND NATHAN M. SCHIFF ${ }^{2}$ \\ 1. Australian Centre for Evolutionary Biology and Biodiversity, and School of Earth and Environmental Sciences, The University of \\ Adelaide, SA 5005, Australia. Contact: john.jennings@adelaide.edu.au \\ 2. USDA Forest Service, SRS-4155, Center for Bottomland Hardwoods Research, P.O. Box 227, Stoneville, MS 38776, USA
}

\begin{abstract}
Xiphydriid woodwasps have been very rarely collected in Australasia although they are widely distributed in the region. Species have been described from the Aru, Ambon and Buru Islands, Indonesia, eastern mainland Australia, Papua New Guinea, and New Zealand. Here Rhysacephala novacaledonica Jennings \& Austin, sp. nov., is described, which is the first record of a xiphydriid woodwasp from New Caledonia. In addition, a key to genera for the region is presented, along with a discussion of the biology and distribution of the group in Australasia.
\end{abstract}

Key words: Xiphydrioidea, taxonomy, Symphyta

\section{INTRODUCTION}

The sawfly family Xiphydriidae (Xiphydrioidea), or woodwasps, is worldwide in distribution, except Africa, and includes some 119 described species (Taeger \& Blank 2006). Xiphydriids are rarely collected in Australasia and poorly represented in collections, with only nine described species in two subfamilies, Derecyrtinae and Xiphydriinae (Benson 1954). Derecyrtinae are restricted to Central and South America except for the monotypic genus Austrocyrta Riek, 1955 from Australia (Riek 1955; Smith 1978). Xiphydriinae occur worldwide (Maa 1949; Smith 1978) and, in Australasia, are known from eight described species; Cingalixiphia laeviceps (F. Smith, 1861) from Ambyona [Ambon] and Buru, Indonesia, Rhysacephala leai (Forsius, 1927), $R$. obtusiventris (Rohwer, 1918) and $R$. wilsoni Benson, 1954 from Australia, R. rufipes (F. Smith, 1859) from the Aru Islands, Indonesia, $R$. testacea (Mocsáry, 1900) from Papua New Guinea, and Moaxiphia decepta (F. Smith, 1876) and M. duniana (Gourlay, 1927) from New Zealand (Smith 1978) (Fig. 1). There are also perhaps a dozen or more undescribed species of Rhysacephala Benson, 1954 known from the Australasian region, including a number from the east coast of mainland Australia, Tasmania, Lord Howe Island (authors unpubl.) and New Caledonia (Smith pers. comm.).

All known xiphydriid larvae are woodborers and have only vestigial legs (Smith \& Middlekauff 1987). In the Northern Hemisphere, larvae are known to develop in the wood of angiosperms, usually in small branches of deciduous trees such as Aceraceae, Betulaceae, Salicaceae, and Ulmaceae (Smith 1976; Smith 1978; Gauld \& Bolton 1996; Smith \& Schiff 2001), where they depend on symbiotic fungi in their tunnels for food for the developing larvae (e.g. Kajimura 2000). Very little is known about the biology of Australasian xiphydriids. In New Zealand, the larvae of $M$. decepta bore in twigs of the evergreen shrub Coprosma robusta Raoul. (Rubiaceae), and the larvae of $M$. duniana tunnel in twigs of the evergreen southern beeches Nothofagus fusca (Hook.f.) Oerst. and N. menziesii (Hook.f.) Oerst. (Fagaceae) (Valentine \& Walker 1991). Basset (1991) noted that Rhysacephala were found in the canopy of an Argyrodendron actinophyllum Edlin (Malvaceae, Sterculieae) forest near Brisbane, Australia, although it is not clear that it is the host. 
Here a new species of Rhysacephala is described, which is the first record the Xiphydrioidea from New Caledonia. Although the leaf blister sawfly Phylacteophaga froggatti Riek, 1955 (Pergidae: Phylacteophaginae) has been accidentally introduced into New Caledonia from Australia (Mayo et al. 1997), this is the first endemic symphytan recorded in the literature for New Caledonia.

Although based on a single male specimen collected during a survey conducted by the Queensland Museum in southeastern New Caledonia, the species is very distinct from other members of Rhysacephala. In addition, we present a key to genera that occur in Australasia and provide an overview of the family for the region.

\section{METHODS, TERMINOLOGY AND ABBREVIATIONS}

Images were taken using a Nikon DXM1200 digital camera attached to a Leica MZ16 microscope. Images were captured with Auto-Montage software ver. 4.02.0014. Morphological terms generally follow Huber \& Sharkey (1993) and terms for surface sculpturing follow Harris (1979).

\section{SYSTEMATICS}

Although the xiphydriid genera occurring in Australasia are well-characterised, their monophyly has not been confirmed, nor is there any information available about their relationships with extralimital genera. For the Derecyrtinae, it is possible that the group is Gondwanan in origin or, alternatively, the group evolved in South America and has dispersed to Australia. Although the latter scenario appears unlikely, long distance dispersal has been proposed as the best explanation for the apparent Gondwanan distribution of the parasitoid subfamily Hyptiogastrinae (Gasteruptiidae) (Jennings \& Austin 2001). Relationships among the Australasian Rhysacephala species, and with Cingalixiphia Maa, 1949 from Indonesia and Moaxiphia Maa, 1949 from New Zealand, are unknown, and yet this information is vital for achieving an understanding of the biogeographic history of the family for the Southern Hemisphere continents and the evolution of their host plant associations. Clearly, a phylogeny for the Xiphydriidae is well overdue.

\section{Key to subfamilies and genera of Xiphydriidae for Australasia}

1. Mesoscutellum with a dorsal area defined by a carina, with prominent tubercle near apex (Fig. 8); fore wing vein $2 \mathrm{r}$ absent; pronotal collar not deeply excavated in front [Derecyrtinae] Austrocyrta Riek Mesoscutellum without dorsal area defined by a carina, without prominent tubercle near apex (Fig. 6); fore wing vein 2r present (Fig. 3); pronotal collar usually deeply excavated in front (Fig. 9) (some undescribed Rhysacephala from Australia apparently do not have a deeply excavated pronotal collar) [Xiphydriinae].....

2. Hind claw simple [Ambon and Baru, Indonesia] …........................................................ngalaxiphia Maa

Hind claw with single erect inner tooth

3. Distance between antennal sockets much less than twice distance between an antennal socket and front of clypeus; inner orbits of eyes very strongly convergent caudad [New Zealand] Moaxiphia Maa Distance between antennal sockets greater than twice distance between an antennal socket and front of clypeus (Fig. 5); inner orbits of eyes more or less parallel [Australia, Papua New Guinea, Aru Islands, New Caledonia] Rhysacephala Benson 


\section{Rhysacephala novacaledonica Jennings \& Austin, sp.nov.}

(Figs 1-7)

\section{Material Examined}

Holotype: $\sigma^{x}$ "New Caledonia $22^{\circ} 14^{\prime S x} 166^{\circ} 50^{\prime} E$ Pic du Pin, site 2, 280m 26Nov2004 hand netting Burwell, Wright, rainforest". Deposited in the Muséum National d'Histoire Naturelle, Paris. Last 5 flagellomeres of left antenna and right hind tarsal segments $2-5$ and claw missing.

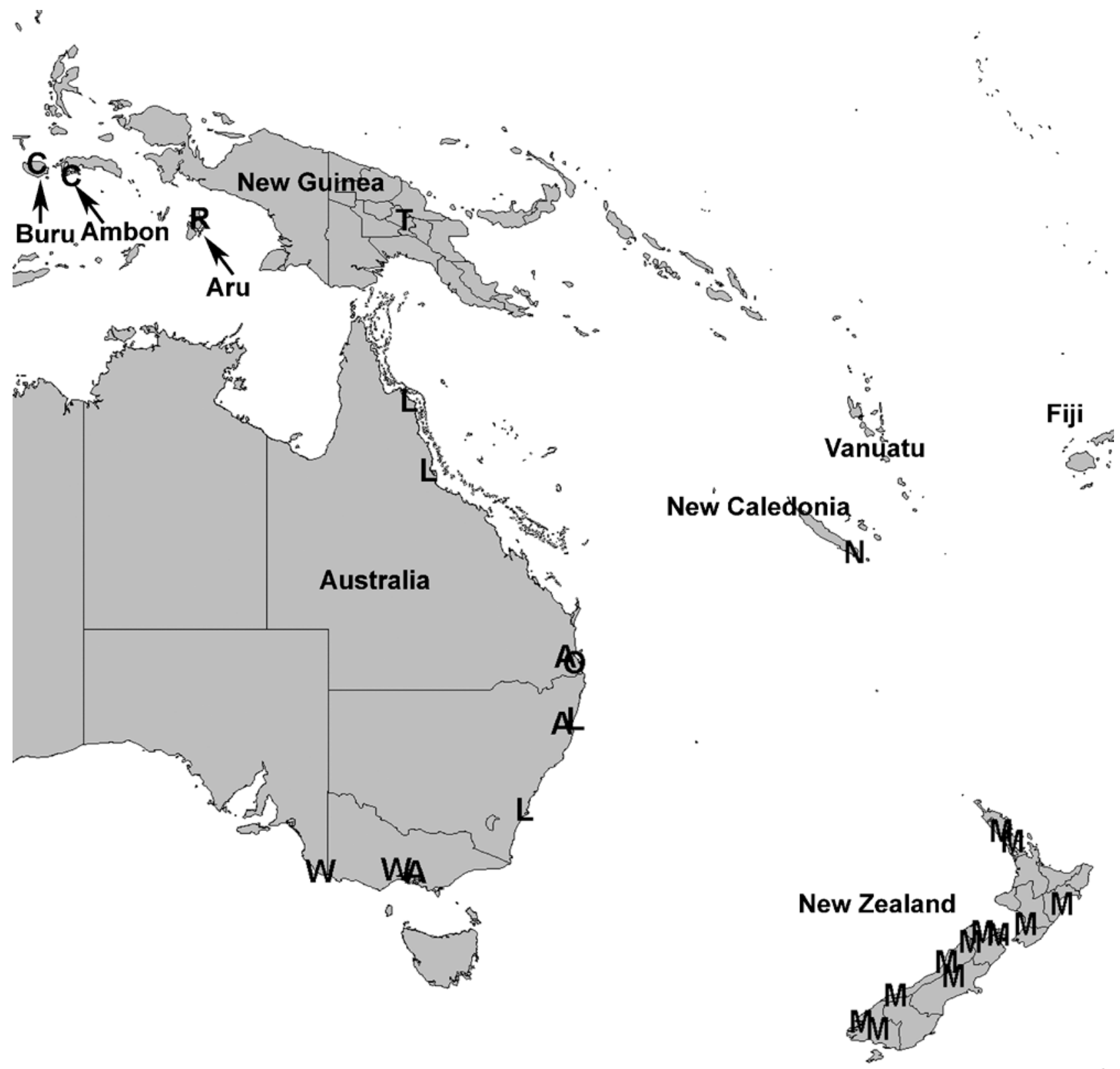

FIGURE 1. Distribution of Xiphydriidae in Australasia. $\mathrm{A}=$ Austrocyrta australiensis Riek; $\mathrm{C}=$ Cingalixiphia laeviceps; $\mathrm{M}=$ Moaxiphia spp.; $\mathrm{L}=$ Rhysacephala leai $; \mathrm{N}=R$. novacaledonica sp. nov.; $\mathrm{O}=R$. obtusiventris $\mathrm{R}=R$. rufipes; $\mathrm{T}=$ R. testacea $;$ and $\mathrm{W}=R$. wilsoni .

\section{Description}

Male: Length $7.0 \mathrm{~mm}$ (Fig 2). Head dark brown, thorax and abdomen black except for a broad yellow stripe on face along lower inner orbits of eyes, gena, malar space and lower hind orbits. Irregular yellow patch 
medially on lower frons and interantennal area, mandible yellow with brown margins, ventral surface of propleuron and thoracic sternites largely yellow, cenchri white, yellow dot medially on mesepisternum, antennae and legs light brown except variable amounts of yellow ventrally on coxae. Fore wing with a dark brown tint, hind wing lighter brown tint (Fig. 3).

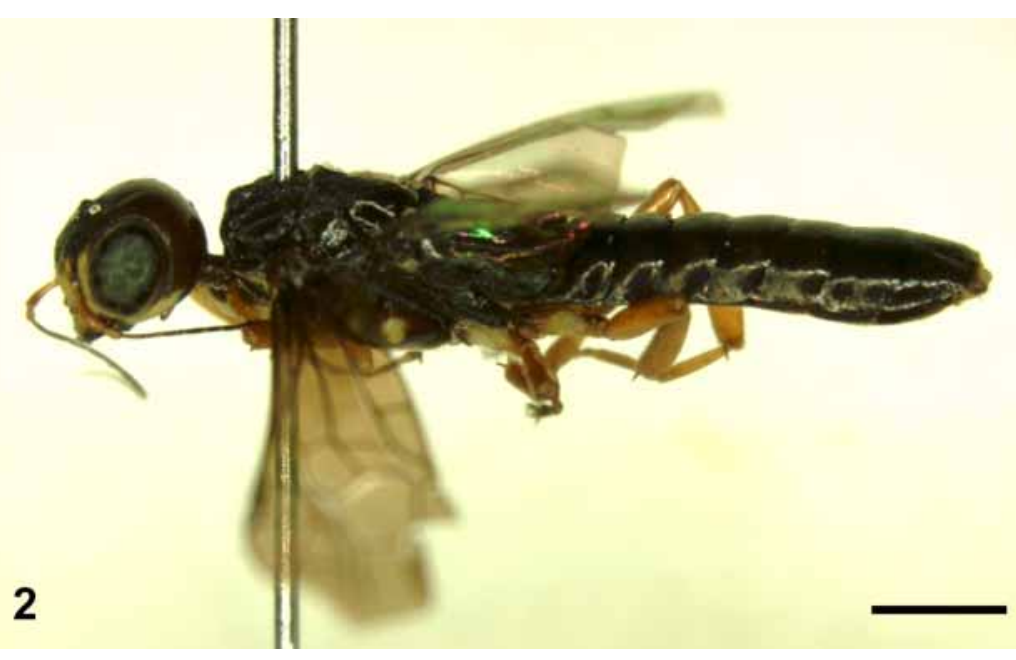

FIGURE 2. Lateral habitus of $R$. novacaledonica sp. nov. Scale bar $=1.0 \mathrm{~mm}$.

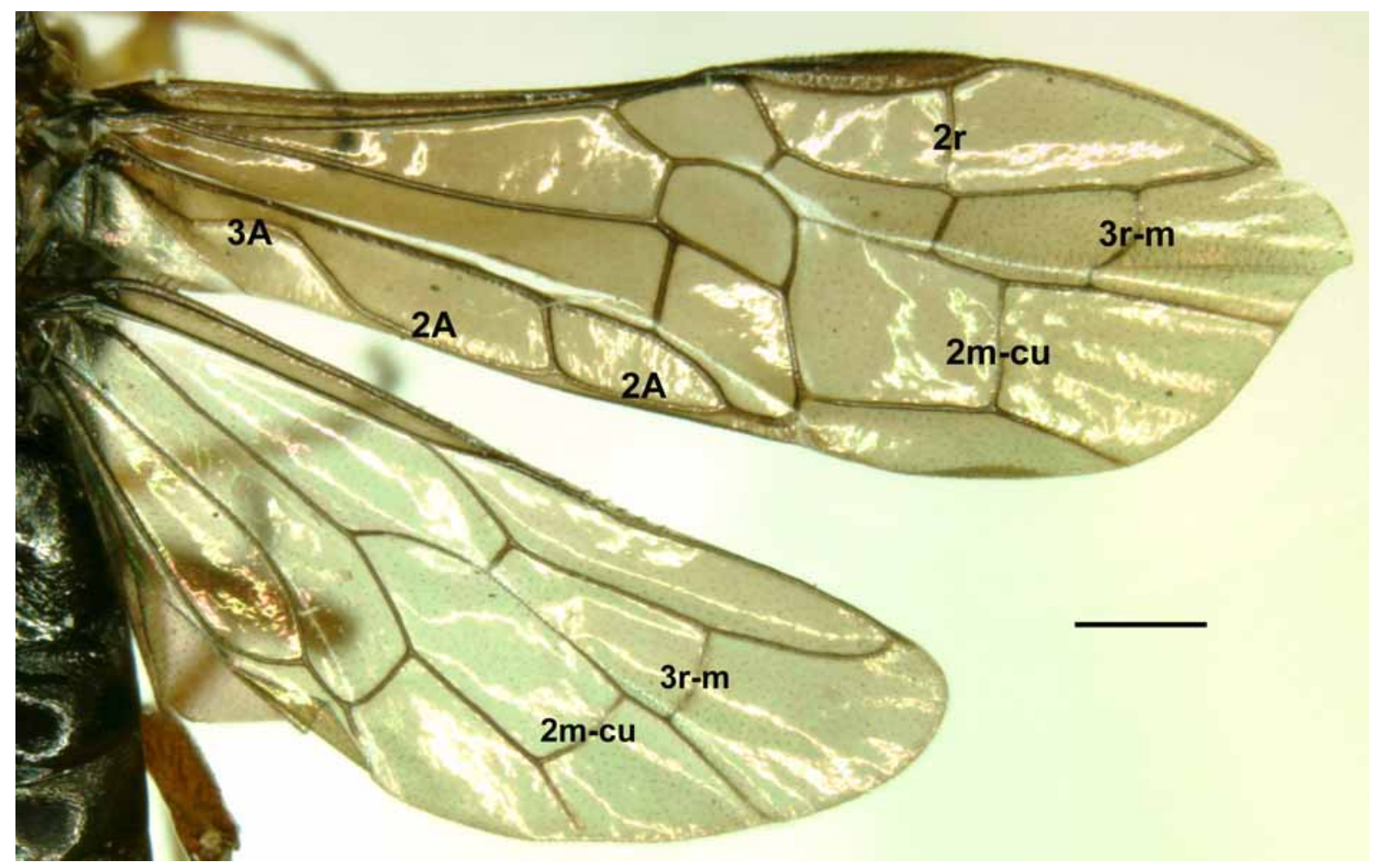

FIGURE 3. Wings of $R$. novacaledonica sp. nov. showing venation. Scale bar $=0.5 \mathrm{~mm}$.

Head $1.24 \mathrm{x}$ wider than long when viewed dorsally (Fig. 4). Face rugose (Fig. 5). Inner orbits of eyes more or less parallel (Fig. 5). Distance between antennal sockets $3 \mathrm{x}$ distance between an antennal socket and front of clypeus (Fig. 5). Vertex smooth except for a few scattered shallow punctures posteromedially, rugose near ocelli (Fig. 4). Gena smooth, carina present. Malar space $0.32 \mathrm{x}$ height of eye, distinct antennal groove. Occipital carina broad (Fig. 4). Clypeus strigate. Mandible 4-dentate. Maxillary palp 7-segmented, labial palp 
4-segmented. Antenna 19-segmented, scape $2.2 \mathrm{x}$ length pedicel, first flagellomere equal to length of scape, $1.7 \mathrm{x}$ as long as second flagellomere. Pedicel $2.3 \mathrm{x}$ longer than wide.

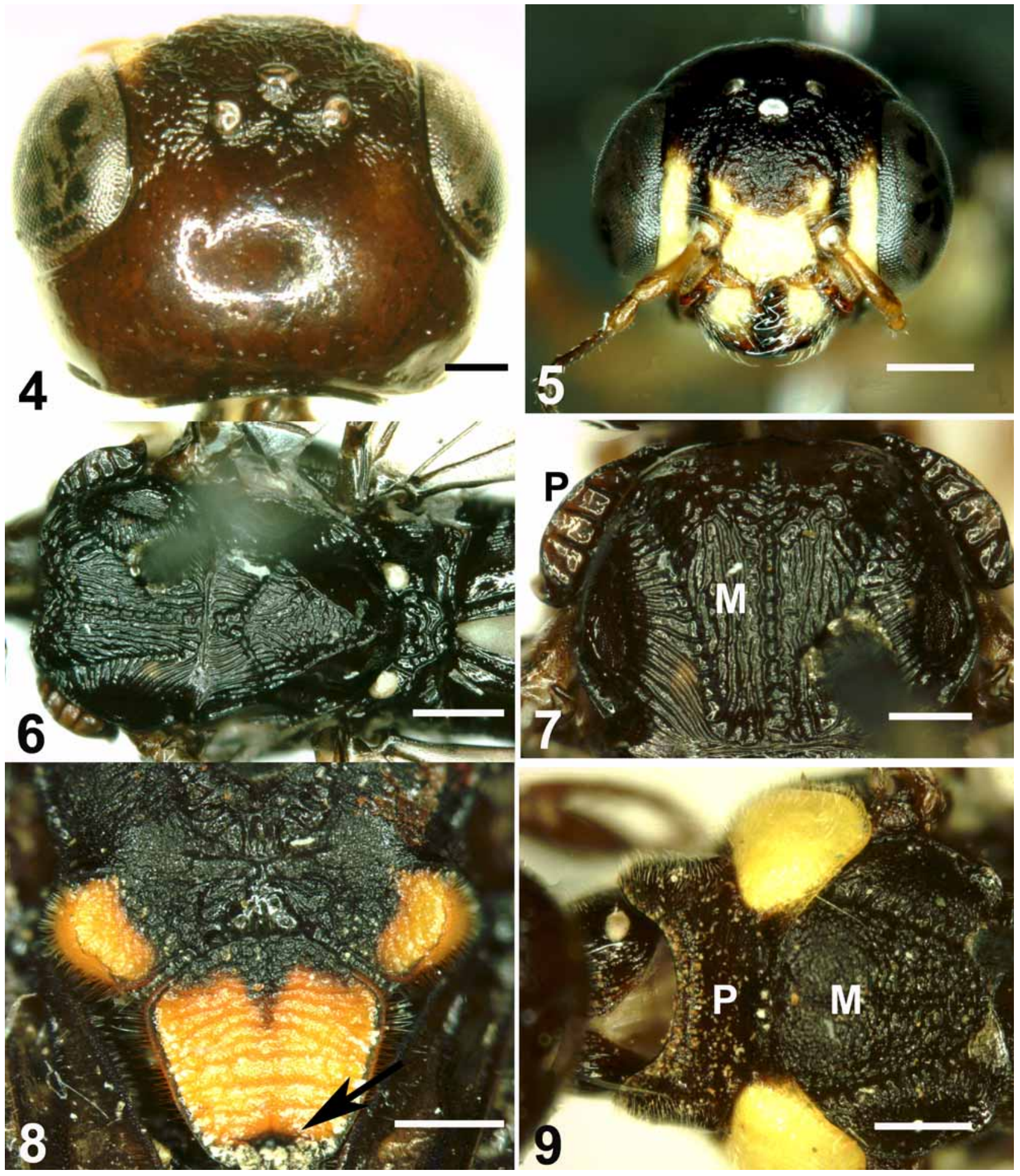

FIGURES 4-9. 4. Dorsal head of $R$. novacaledonica sp. nov.; 5. Frontal head of $R$. novacaledonica sp. nov.; 6. Dorsal thorax of $R$. novacaledonica sp. nov.; 7. Dorsal view of mesoscutum (M) and lateral corner of pronotum (P) of $R$. novacaledonica sp. nov.; 8. Dorsal scutellum, axillae and mesoscutellum of male of an undescribed Austrocyrta sp. from Mt Moffatt, Queensland, showing tubercule (arrowed) on scutellum; 9. Dorsal view of pronotal collar (P) and mesoscutum (M) of A. australiensis, female. Scale bars 4-6, 8-9 $=0.2 \mathrm{~mm} ; 7=0.15 \mathrm{~mm}$. 
Pronotal collar hidden on specimen, lateral corner carinate (Fig. 7). Mesoscutum strigate, with reticulate microsculpturing, medial patch on lateral mesoscutum reticulate (Figs 6,7). Mesoscutellum without dorsal area defined by a carina, without prominent tubercle near apex (Fig. 6). Axillae strigate. Metascutellum strigate with reticulate microsculpturing. Metapostnotum and mesepisternum rugose. Mesopleuron rugose anteriorly, imbricate posteriorly. Metapleuron rugose dorsally, rugulose ventrally. Mesepimeron broad, carinate. Hind femur $0.9 \mathrm{x}$ length hind tibia. Tibiae with two apical spurs, although inner one very short on fore tibia. Hind basitarsus slightly longer than remaining segments combined, bilobed tarsal plantulae present distally on segments 1-4. Tarsal claws with small erect inner tooth. Fore wing vein $2 \mathrm{~A}+3 \mathrm{~A}$ complete, more or less even in colouration although apical part slightly paler, almost reaching wing margin (Fig. 3). Hind wing veins $3 \mathrm{r}-\mathrm{m}$ and $2 \mathrm{~m}$-cu present (Fig. 3). Hind wing with 5 hamuli basally and 6 hamuli medially. Abdomen 2.4 $\mathrm{x}$ length thorax (Fig. 2), reticulate microsculpturing.

Female: Unknown.

\section{Remarks}

This species lacks a prominent tubercle near the apex of the mesoscutellum (Fig. 6) placing it in the Xiphydriinae rather than the Derecyrtinae. It also has bilobed tarsal plantulae which are absent in most Derecyrtinae (Benson 1954; Smith 1978; Schulmeister 2003), although present in A. australiensis Riek (Jennings unpublished). It exhibits the main characteristics for Rhysacephala as defined by Maa (1949), and modified by Benson (1954), including the inner orbits of the eyes being more or less parallel and having 7-segmented maxillary palps. The fore wing vein $2 \mathrm{~A}+3 \mathrm{~A}$ is more or less even in colour although apically a little paler, and almost reaches the wing margin (Fig. 3); in this respect it is not too dissimilar to the original diagnosis for the genus (Maa 1949; Benson 1954). Any differences are relatively minor and do not require the generic limits of Rhysacephala to be modified to accommodate this new species.

Although this species is similar in colour to the females of both $R$. obtusiventris and $R$. rufipes in which both the thorax and abdomen are black, it differs from the female of $R$. wilsoni which has a black thorax and a reddish brown abdomen, Rhysacephala novacaledonica can be distinguished from the male of $R$. leai in which both the thorax and abdomen are pale reddish brown. It can be distinguished from the male of $R$. testacea which also has the abdomen "infuscatus" (darkened), by $R$. novacaledonica having 19-segmented antennae compared with 13-segmented in R. testacea (Mocsáry 1900). It should be noted that a degree of caution must be exercised when comparing the colouration of different sexes as there is often a difference between the sexes.

The head of $R$. novacaledonica is similar to that of $R$. leai. Both have a broad yellow stripe on the face along the lower inner orbits of the eyes, gena, malar space and lower hind orbits, although the remainder of the head of $R$. leai is black whereas it is brown in $R$. novacaledonica (Fig. 5). It differs from R. obtusiventris, $R$. rufipes, $R$. testacea, and $R$. wilsoni which lack a stripe on the face and gena. It is interesting to note that Cingalixiphia laeviceps, which is distinguished from Rhysacephala by having a simple hind claw, also has a similar yellowish-white stripe (Smith 1861).

Rhysacephala novacaledonica is known only from the type locality, Pic du Pin, New Caledonia (Fig. 1), and is named after this island. The name is to be treated as an adjective. Its biology is unknown. In Brazil, the xiphydriid woodwasp Derecyrta araucariae Mecke is associated with Araucaria angustifolia (Bertol.) Kuntze (Mecke et al. 2000). Some 13 species of Araucaria and five species of Agathis (Araucariaceae) are endemic to New Caledonia (Lowry 1998), and it seems reasonable to hypothesise that xiphydriid woodwasps may be associated with Araucariaceae in New Caledonia. Similarly, D. beechei Smith (Cupressaceae) has been collected in Chile from Fitzroya cupressoides (Molina) Johnston forest (Smith 1995), so other potential hosts in New Caledonia might also include Cupressaceae. Both Callitris spp. and Neocallitropsis spp. occur in New Caledonia (Pye et al. 2003). Finally, Basset (1991) noted that Rhysacephala were found in the canopy of an Argyrodendron actinophyllum forest near Brisbane, Australia, although it is not clear whether it is its host. 
Whilst Argyrodendron is an Australian genus, the genus Acropogon, with more than 20 species endemic to New Caledonia (Morat \& Chalopin 2005), might be worth exploring as potential hosts.

\section{ACKNOWLEDGEMENTS}

We thank David Smith, Smithsonian Institution, Washington, D.C. and Susanne Schulmeister, Museum of Natural History, New York for reviewing and vastly improving the manuscript. We also thank Chris Burwell, Queensland Museum, Brisbane, for drawing our attention to the specimen of R. novacaledonica, and the following curators for the loan of xiphydriid material in their care: John LaSalle, Australian National Insect Collection, Canberra; Stuart Hine, The Natural History Museum, London; Ken Walker, Museum of Victoria, Melbourne; and Jan Forrest, South Australian Museum, Adelaide. This work was carried out with the assistance of an Australian Biological Resources Study grant to Jennings and Schiff.

\section{REFERENCES}

Benson, R.B. (1954) Classification of the Xiphydriidae (Hymenoptera). Transactions of the Royal Entomological Society of London, 105, 151-162.

Basset, Y. (1991) The taxonomic composition of the arthropod fauna associated with an Australian rain-forest tree. Australian Journal of Zoology, 39, 171-190.

Gauld, I.D. \& Bolton, B. (eds.) (1996) The Hymenoptera. 2nd. ed. (Oxford University Press, Oxford). 332 pp.

Huber, J.T. \& Sharkey, M.J. (1993) Structure. pp. 13-59. In Goulet, H. \& Huber, J.T. (eds.). Hymenoptera of the world: An identification guide to families. Research Branch, Agriculture Canada. Publication 1894/E.

Harris, R.A. (1979) A glossary of surface sculpturing. Californian Department of Food and Agriculture, Bureau of Entomology, Occasional Papers, 28, 1-28.

Jennings, J.T. (2006) Xiphydrioidea. [Australian Faunal Directory] (http://www.deh.gov.au/biodiversity/abrs/onlineresources/fauna/afd/).

Jennings, J.T. \& Austin, A.D. (2002) Systematics and distribution of world hyptiogastrine wasps (Hymenoptera: Gasteruptiidae) Invertebrate Systematics, 16, 735-811.

Kajimura, H. (2000) Discovery of mycangia and mucus in adult female xiphydriid woodwasps (Hymenoptera: Xiphydriidae) in Japan. Annals of the Entomological Society of America, 93, 312-317.

Lowry, P.P. (1998) Diversity, endemism, and extinction in the flora of New Caledonia: a review. pp. 181-206. In Peng, C.-I. \& Lowry, P.P. (eds.), Rare, Threatened, and Endangered Floras of the Pacific Rim. Institute of Botany, Academica Sinica, Monograph Series No. 16, Taipei.

Maa, T. (1949) A synopsis of Asiatic Siricoidea with notes on certain exotic and fossil forms (Hymenoptera Symphyta). Notes d'Entomologie Chinoise, 13, 11-189.

Mayo, G.M., Austin, A.D \& Adams, M. (1997) Morphological and electrophoretic taxonomy of the Australian leaf-blister sawflies, Phylacteophaga spp. (Hymenoptera: Pergidae). Bulletin of Entomological Research, 87, 595-608.

Mecke, R., Barbosa, M.C. \& Engels, W. (2000) A new Brazilian sawfly, Derecyrta araucariae spec. nov. (Hymenoptera: Xiphydriidae), associated with Araucaria angustifolia (Bert.) O. Kuntze. Journal of the Kansas Entomological Society, 73, 177-182.

Mocsáry, A. (1900) Siricidarum species duae novae. Természetrajzi Füzetek, 23, 126-127.

Morat, P. \& Chalopin, M. (2005) Quatre autres nouvelles espèces d'Acropogon Schltr. (Malvaceae, Sterculieae) endémiques de Nouvelle-Calédonie. Adansonia, 3 27, 255-266.

Pye, M.G., Gadek, P.A. \& Edwards, K.J. (2003) Divergence, diversity and species of the Australasian Callitris (Cupressaceae) and allied genera: evidence from ITS sequence data. Australian Systematic Botany 16, 505-514.

Riek, E.F. (1955) The Australian Xiphydriidae (Hymenoptera: Symphyta). Australian Journal of Zoology 3, 281-285.

Schulmeister, S. (2003) Morphology and evolution of the tarsal plantulae in Hymenoptera (Insecta), focussing on the basal lineages. Zoologica Scripta, 32, 153-172.

Smith, D.R. (1976) The xiphydriid woodwasps of North America (Hymenoptera : Xiphydriidae). Transactions of the American Entomological Society, 102, 101-131.

Smith, D.R. (1978) Suborder Symphyta (Xyelidae, Pararchexyelidae, Parapamphiliidae, Xyelydidae, Karatavitidae, Gigasirididae, Sepulcidae, Pseudosiricidae, Anaxyelidae, Siricidae, Xiphydriidae, Paroryssidae, Xyelotomidae, Blasticotomidae, Pergidae). In: van der Vecht, J. \& Shenefelt, R.D., eds. Hymenopterorum catalogus. W. Junk. The 
Hague. Pars 14, 198 pp.

Smith, D.R. (1988) A synopsis of the sawflies (Hymenoptera: Symphyta) of America south of the United States: Introduction, Xyelidae, Pamphiliidae, Cimbicidae, Diprionidae, Xiphydriidae, Siricidae, Orussidae, Cephidae. Systematic Entomology, 13, 205-261.

Smith, D.R. (1995) A new species of Xiphydriidae (Hymenoptera) from Chile. Revista Chileana de Entomología, 22, 21-24.

Smith, D.R. \& Middlekauff, W.W. (1987) Suborder Symphyta, pp. 618-649. In: Stehr, F.W., (ed.). Immature Insects, Kendall Hunt Publishing Company. 754 pp.

Smith, D.R. \& Schiff, N.M. (2001) A new species of Xiphydria Latreille (Hymenoptera: Xiphydriidae) reared from river birch, Betula nigra L., in North America. Proceedings of the Entomological Society of Washington, 103, 962-967.

Smith, F. (1861) Catalogue of Hymenopterous insects collected by Mr. A. R. Wallace in the islands of Bachian, Kaisaa, Amboyna, Gololo, and at Dory in New Guinea. Journal of the Linnaean Society of London, 5, 93-143.

Taeger, A. \& Blank S.M. (2006) ECatSym - Electronic World Catalog of Symphyta (Insecta, Hymenoptera).- Version 2.0 (August 11, 2006). ECatSym Online Service Müncheberg,

http://www.zalf.de/home_zalf/institute/dei/php_e/ecatsym/ecatsym.php.

Valentine, E.W. \& Walker, A.K. (1991) Annotated catalogue of New Zealand Hymenoptera. DSIR Plant Protection Report No. 4. 84 pp. 